Article

\title{
Comparison of Aqueous and Gelled 3.5\% NaCl Electrolytes for Assessing the Corrosion Resistance of Thermal Spray Stainless-Steel Coatings in Electrochemical Corrosion Tests
}

\author{
Pia Kutschmann ${ }^{1, *}$, Maximilian Grimm ${ }^{1}{ }^{(D}$, Thomas Lindner ${ }^{1}$ (D), Kerstin Raffaela Ernst ${ }^{2}$, Olga Schwabe $^{2}$, \\ Christian Pluta ${ }^{3}$ and Thomas Lampke ${ }^{1, * \mathbb{D}}$ \\ 1 Materials and Surface Engineering Group, Institute of Materials Science and Engineering, \\ Chemnitz University of Technology, D-09107 Chemnitz, Germany; \\ maximilian.grimm@mb.tu-chemnitz.de (M.G.); th.lindner@mb.tu-chemnitz.de (T.L.) \\ 2 Putzier Oberflächentechnik GmbH, D-42799 Leichlingen, Germany; kerstin.ernst@putzier.com (K.R.E.); \\ olga.schwabe@putzier.com (O.S.) \\ 3 JELN Imprägnierung GmbH, D-41366 Schwalmtal, Germany; info@jeln.de \\ * Correspondence: pia.kutschmann@mb.tu-chemnitz.de (P.K.); thomas.lampke@mb.tu-chemnitz.de (T.L.)
}

check for updates

Citation: Kutschmann, P.; Grimm, M.; Lindner, T.; Ernst, K.R.; Schwabe, O.; Pluta, C.; Lampke, T. Comparison of Aqueous and Gelled 3.5\% NaCl Electrolytes for Assessing the Corrosion Resistance of Thermal Spray Stainless-Steel Coatings in Electrochemical Corrosion Tests. Coatings 2022, 12, 344. https:// doi.org/10.3390/coatings12030344

Academic Editors: Ramachandran Chidambaram Seshadri and

A.K. Lakshminarayanan

Received: 2 February 2022

Accepted: 3 March 2022

Published: 6 March 2022

Publisher's Note: MDPI stays neutral with regard to jurisdictional claims in published maps and institutional affiliations.

Copyright: (C) 2022 by the authors. Licensee MDPI, Basel, Switzerland. This article is an open access article distributed under the terms and conditions of the Creative Commons Attribution (CC BY) license (https:// creativecommons.org/licenses/by/ $4.0 /)$.

\begin{abstract}
Corrosion testing with gel electrolytes gained attention in the past decade due to the advantage of almost non-destructive and in situ electrochemical measurements of bulk materials. Regarding thermal spray coatings, gel electrolytes offered the opportunity to prevent the infiltration of the typical microstructural features such as pores and microcracks. Using the example of stainlesssteel AISI 316L coatings deposited by high velocity air fuel (HVAF) spraying on mild and stainlesssteel substrates, the electrochemical corrosion behavior was analyzed in 3.5\% $\mathrm{NaCl}$ electrolytes in an aqueous and gelled state. In this context, potentiodynamic polarization tests were carried out in a three-electrode corrosion cell, which was adapted for gel electrolyte testing. Gelling was realized with a technical gelatin. The characteristic corrosion values, such as open circuit potential, corrosion potential, and corrosion current density, revealed for the gelled state that the influence of the substrate material used could be eliminated and thus, the coatings itself could be characterized. In contrast, the coating specific microstructure and substrate material significantly affected the potentiodynamic polarization curve in the $3.5 \% \mathrm{NaCl}$ aqueous electrolyte. Optical microscopy of the coating surfaces and cross-sections proved that the corrosion attack caused by aqueous electrolytes could be mimicked with the gel electrolyte.
\end{abstract}

Keywords: gel electrolyte; thermal spray coatings; electrochemical corrosion; stainless steel; AISI 316L; HVAF

\section{Introduction}

Gel electrolytes are increasingly considered in corrosion science with the focus on visual corrosion inspection for specific applications and electrochemical-instrumented measurements [1-12]. The advantages addressed are an easier handling than using liquid electrolytes, e.g., for geometrical complex structures, almost non-destructive measurements, and the imitation of specific atmospheres. In most cases, the electrolytes are gelatinized by Agar, a polycarbohydrate, which are often stabilized by adding additives. One established corrosion test is the KorroPad indication test, which is designed for passivating steels to evaluate their susceptibility concerning pitting corrosion [1-3]. Further applications are corrosion assessment at sculptures and monuments $[4,8]$ and reconstruction of specific atmospheric conditions like moisturizing films on zinc coatings [6,12] or artificial mud [11].

With regard to thermal spray coatings, Kutschmann et al. showed in a previous study that an infiltration of the characteristic microstructures, such as pores and cracks, of arc and plasma-sprayed AISI 316L coatings can be prevented when using gel electrolytes in 
electrochemical-instrumented corrosion tests [13]. The corrosion attack can be transferred to the surface and the corrosion properties of the coating itself and the applied spraying conditions are revealed.

The corrosion behavior of thermal spray coatings is generally investigated with focus on the composite of the coating and the substrate not normally differentiating the substrate material used. Hence, the applied corrosion tests are generally destructive. The salt spray test or the Corrodkote test are specifically designed to induce sub-corrosion in order to test the apparent density of the coatings. In research, studies often deal with electrochemicalinstrumented tests such as potentiodynamic polarization, electrochemical impedance, and immersion tests in $3.4 \%$ to $5 \%$ sodium chloride $(\mathrm{NaCl})$ solutions [14-17]. For these corrosion tests, the following observations can be summarized: the open circuit potential $(\mathrm{OCP})$ and the corrosion potential $\left(\mathrm{E}_{\mathrm{Corr}}\right)$, respectively, decreases with immersion time due to electrolyte infiltration of the coating toward the substrate. Consequently, a galvanic pair emerges between the coating and substrate resulting in the detection of mixed potentials. Hence, thermal spray coatings with a homogeneous and compact coating microstructure with less oxidation are preferred for corrosive application. In order to improve the corrosion behavior, several authors studied the influence of the spray parameters [15-21] or post treatments like sealing [22-24] or heat treatments $[18,25,26]$. Post treatments are cost and time consuming and can alter the substrate. Nevertheless, influencing factors still are fluctuations in the coating process or deviations in the quality of the feedstock material. Image analysis methods are not capable to detect these changed spraying conditions in the coating microstructure. Corrosion tests can be used to assess such defects [25].

A novel corrosion test for thermal spray coatings using gel electrolytes describes the potential of characterizing the corrosion behavior of the coating itself. On the one hand, gel electrolytes attack only the coating surface and prevent coating damage up to the substrate. As a result, an almost non-destructive test strategy can be provided, which can be transferred on coated components as well. On the other hand, an electrochemicalinstrumented corrosion test based on the three-electrode cell enables a quantitative and timeless assessment of the corrosion resistance. Both advantages can be utilized to establish a test method for quality assurance during production. This study focuses on the influence of the substrate material on the measured corrosion values using potentiodynamic polarization tests in aqueous and gelled 3.5\% NaCl electrolytes. Stainless-steel AISI 316L coatings were produced by the high velocity air fuel (HVAF) spraying process on structural steel (EN 1.0117) and stainless steel (EN 1.4404 corresponds to AISI 316L) substrates, respectively providing coatings with minimal defects such as porosity, in situ oxidation, and depletion of beneficial elements like $\mathrm{Cr}$.

\section{Materials and Methods}

\subsection{Coating Production and Characterization}

Stainless-steel coatings were produced with a HVAF M3 ${ }^{\mathrm{TM}}$ equipment (Uniquecoat Technologies, LLC, Oilville VA, USA). Gas-atomized AISI 316L stainless-steel powder was chosen as feedstock material. Propane and air were combusted to accelerate the powder, and nitrogen was used as carrier gas for coating deposition. Thus, coatings with a thickness of $\sim 300 \mu \mathrm{m}$ were deposited on mild steel and stainless-steel substrates. As substrate samples, $100 \mathrm{~mm} \times 100 \mathrm{~mm} \times 4 \mathrm{~mm}$ structural steel plates (EN 1.0117), further labelled as mild steel, and $\varnothing 25 \mathrm{~mm} \times 5 \mathrm{~mm}$ stainless-steel coupons (EN 1.4404) were used as substrate and uncoated reference materials. Before coating deposition, the samples were grit blasted with corundum and cleaned with a strong compressed air flow.

After coating preparation, the steel plates were cut into $20 \mathrm{~mm} \times 20 \mathrm{~mm} \times 4 \mathrm{~mm}$ pieces, flat grounded to a coating thickness of $200 \mu \mathrm{m} \pm 18 \mu \mathrm{m}$ and afterwards diamond polished according to standard metallographic sample preparation up to $1 \mu \mathrm{m}$ diamond polish. The surface preparation routine was used for all coated samples. The reference bulk materials obtained the same polishing surface finish as the coated samples. 
For characterization, metallographic cross-sections of the powder, coating, and reference samples were prepared by standard metallographic procedures. The cross-sections were investigated with an optical microscope GX51 (Olympus, Shinjuku, Japan) equipped with a SC 50 camera (Olympus, Shinjuku, Japan). The coatings' porosities, as an average of five measurements, were evaluated using a digital image analyzing method provided by the camera software. In order to study the powder and coating microstructure in detail, a scanning electron microscope (SEM) LEO 1455VP (Zeiss, Jena, Germany) with an acceleration voltage of $25 \mathrm{kV}$ was used. The AISI 316L powder particle size distribution was examined with a laser particle size analyzer CILAS930 (Cilas, Orléas, France). Chemical compositions were analyzed by energy dispersive X-ray spectroscopy EDS (GENESIS, EDAX, Mahwah, NJ, USA). The corroded surface areas were additionally visualized with a stereo microscope MVX10 (Olympus, Shinjuku, Japan).

\subsection{Corrosion Testing}

The corrosion behavior of the AISI 316L coatings and reference bulk materials was investigated in a stagnant and naturally aerated $3.5 \% \mathrm{NaCl}$ electrolytes, corresponding to $0.56 \mathrm{M} \mathrm{NaCl}$ electrolyte, using the potentiodynamic polarization test. As cell setup the conventional three-electrode configuration were used (Figure 1), in which the test sample acts as the working electrode (WE), a platinum sheet serves as a counter electrode (CE) and the third one is a reference electrode (RE and G-RE, respectively). For the corrosion experiments in the aqueous electrolyte, the $\mathrm{RE}$ was an $\mathrm{Ag} / \mathrm{AgCl}$-saturated $\mathrm{KCl}$ electrode (+0.197 V vs. SHE), which was contacted by a Haber-Luggin capillary (HL) and an electrolyte bridge with the cell circuit (Figure 1a). The $3.5 \% \mathrm{NaCl}$ solution with a $\mathrm{pH}$ value of 5.9 at $23{ }^{\circ} \mathrm{C} \pm 2{ }^{\circ} \mathrm{C}$ was exchanged after each experiment, the volume being $200 \mathrm{~mL}$.

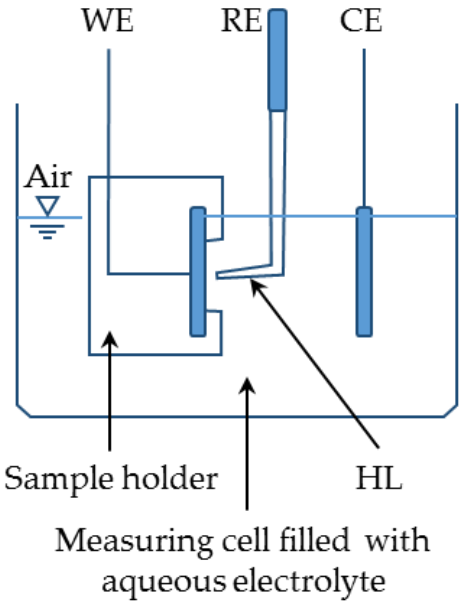

(a)

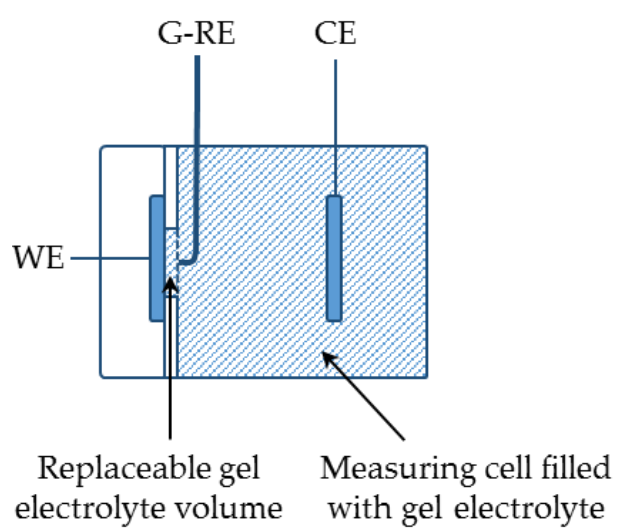

(b)

Figure 1. Schematic setup of the three-electrode configuration for polarization measurements in (a) aqueous solution (standard setup) and (b) gel electrolyte with WE = working electrode-test sample, $\mathrm{RE}=$ reference electrode- $\mathrm{Ag} / \mathrm{AgCl}$ saturated $\mathrm{KCl}, \mathrm{CE}=$ counter electrode-platinum sheet, $\mathrm{HL}=$ Haber-Luggin capillary, G-RE = reference electrode-platinum wire.

For the gel electrolyte tests, a measuring cell was developed based on the threeelectrode arrangement that permits an improved user-friendliness compared to the standard measuring cell, which allows a rapid corrosion test directly on a component surface in later development stages. The position and shape of the counter electrode was kept as in the established three-electrode configuration (Figure 1b). The Haber-Luggin capillary and $\mathrm{Ag} / \mathrm{AgCl} \mathrm{RE}$ were replaced by a platinum wire $(\mathrm{G}-\mathrm{RE},+1.12 \mathrm{~V}$ vs. SHE) with a diameter of $0.5 \mathrm{~mm}$ and placed a few $100 \mu \mathrm{m}$ in front of the surface of the WE. The gel electrolyte studied consisted of a $3.5 \% \mathrm{NaCl}$ solution, which was gelled by using a mass fraction of $30 \%$ 
of a technical gelatin and further addition of preservatives and substances to prevent bubble formation, etc. At room temperature, the gel has a viscosity higher than $3000 \mathrm{mPa} \cdot \mathrm{s}$, which was measured with a viscometer at $37^{\circ} \mathrm{C}$. The electrical resistance of the gel electrolyte is comparable to the aqueous $\mathrm{NaCl}$ solution. The measuring cell was filled with a gel at a temperature of approximately $50{ }^{\circ} \mathrm{C}$, at which the gel has a low viscosity of $\sim 2000 \mathrm{mPa} \cdot \mathrm{s}$. The gel with a volume of $150 \mathrm{~mL}$ to $200 \mathrm{~mL}$ was then allowed to cool to room temperature. After each measurement, a small volume of gel electrolyte $(\sim 10 \mathrm{~mL})$ contaminated with corrosion products was replaced (Figure $1 \mathrm{~b}$, replaceable gel electrolyte volume).

The measurement conditions were kept constant with the focus on implementing a rapid test strategy. Before starting the potentiodynamic polarization scan, the open circuit potential (OCP) was measured for $15 \mathrm{~min}$. An exception is the OCP measurement of the reference mild steel with a duration of $10 \mathrm{~min}$ due to the occurrence of rust traces on the sample surface within $15 \mathrm{~min}$ of immersion time in the aqueous electrolyte. The scan rate was $1 \mathrm{mV} / \mathrm{s}$, scanning a potential range of $-100 \mathrm{mV}$ to $+300 \mathrm{mV}$ relative to the measured $\mathrm{OCP}$. Although a $1 \mathrm{mV} / \mathrm{s}$ was adopted in this stage of the experimentations, it is remarked that potential scan rate has no substantial provided distortions in the polarization curves or the polarization parameters (e.g., corrosion current density $\mathrm{i}_{\text {Corr }}$ and corrosion potential $\left.\mathrm{E}_{\mathrm{Corr}}\right)$ obtained. However, it is worth noting that potential scan rate has an important role in order to minimize the effect of distortion in Tafel slopes and corrosion current density analyses, as previously reported [27-29]. In addition, anodic potential scans up to $+1000 \mathrm{mV}$ relative to the OCP were performed in order to compare the corrosion attack of the aqueous and gel electrolyte. For both measuring cells, a sample area of $10 \mathrm{~mm}$ in diameter were exposed to the electrolyte. The recording of the OCP and the polarization curves were carried out with an electrochemical workstation ZAHNER ZENNIUM and the ThalesXT 5.6.0 USB software package (Zahner Elektrik GmbH \& Co. KG, Kronach, Germany). The corrosion current density $\mathrm{i}_{\mathrm{Corr}}$ and corrosion potential $\mathrm{E}_{\mathrm{Corr}}$ were computed by Tafel analysis. Linear portions of the anodic and cathodic curves were fitted by Tafel exploration using a self-provided MATLAB R2020a (9.8.0.1323502) script. Mainly, the cathodic and anodic curves $\pm 50 \mathrm{mV}$ around the $\mathrm{E}_{\text {Corr }}$ are essential for the determination of $\mathrm{i}_{\text {Corr }}$. All sample surfaces were rinsed with deionized water and degreased using ethanol before starting the corrosion tests. At least three samples were tested for each sample type and electrolyte, respectively. For the characteristic values, OCP, $\mathrm{E}_{\mathrm{Corr}}$, and $\mathrm{i}_{\mathrm{Corr}}$, the mean and standard deviations are reported and in the diagrams, one representative curve is shown for each case.

\section{Results and Discussion}

\subsection{AISI 316L Powder and HVAF Coating Characterization}

The AISI 316L powder used has a predominately spherical particle shape (Figure 2a), which generally results in good flow properties. The backscattered scanning electron microscope image (BSD-SEM) reveals a homogeneous alloy distribution. The particle size analyzed with laser particle size analyzer CILAS verifies a narrow distribution of $-66 \mu \mathrm{m}+28 \mu \mathrm{m}$ (Figure $2 \mathrm{~b}$ ), which is preferred for producing coating microstructures with less-oxidized particle inclusions and pores.

Figure 3 shows an overview of both AISI 316L HVAF coatings on mild steel and stainless-steel substrate with a polished surface finish. Both coatings reveal a dense microstructure with distinguishable particle boundaries, i.e., the spraying parameters enabled a good compaction with few pores. The porosity was quantified to $<1.5 \%$ for the deposition on mild steel and $<1.3 \%$ on stainless steel, respectively. Thus, both coatings systems have comparable microstructures as well as coating thicknesses of $\sim 200 \mu \mathrm{m}$. 


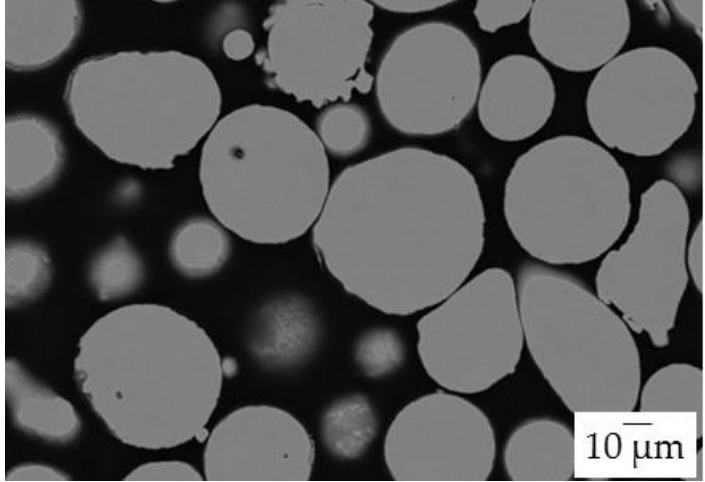

(a)

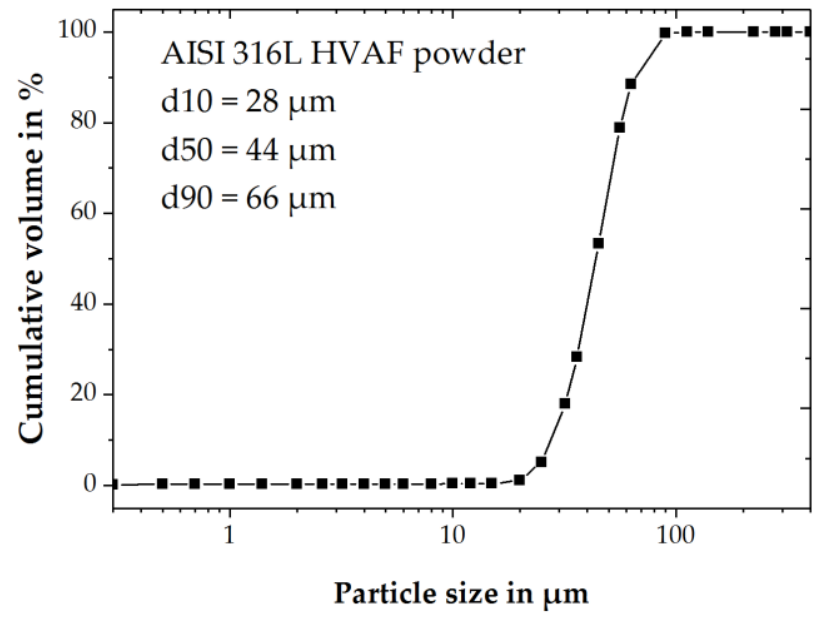

(b)

Figure 2. Characterization of the AISI 316L powder: (a) BSD-SEM image and (b) particle size distribution measured with laser particle size analyzer CILAS.

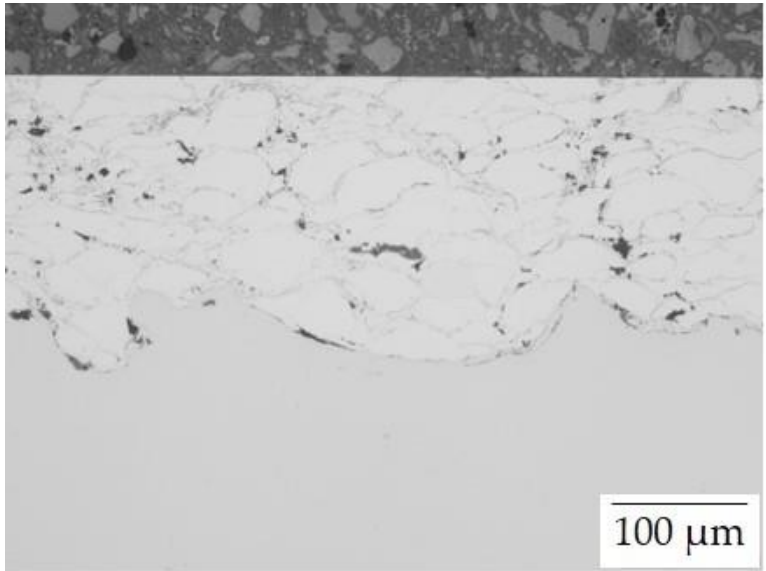

(a)

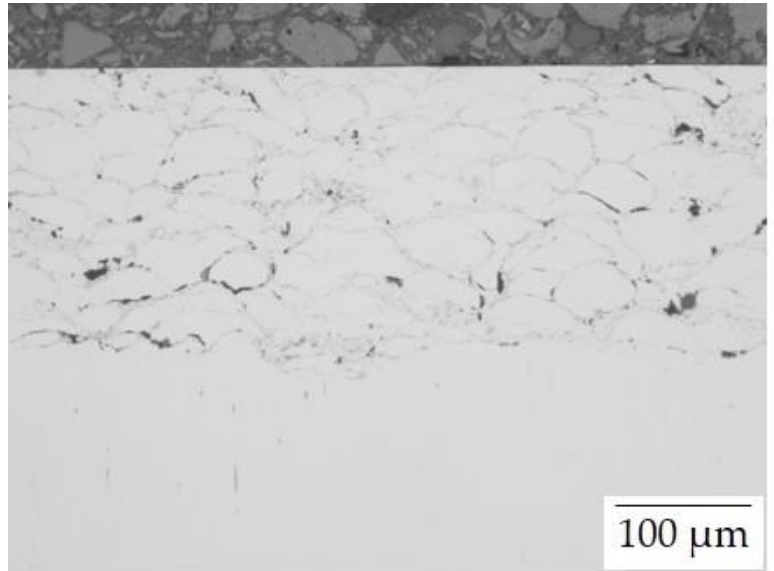

(b)

Figure 3. Light microscopic comparison of the AISI 316L coatings deposited by HVAF process on (a) mild steel and (b) stainless steel in the polished surface finish state before corrosion measurements.

In addition, one coating system was examined in detail in a SEM (Figure 4a). Between the single spray particles, agglomerates of fine and oxidized particles were built into the coating layer. The dark contours at the spray particle surfaces much likely correspond to thin oxide layers. According to EDS analysis (Figure 4b), the powder and spray particle composition lies within the nominal composition of an AISI 316L alloy, this means the chemical composition of the feedstock material is retained in the coatings. These findings coincide with the study by Milanti et al., who characterized AISI 316L coatings sprayed with 2nd and 3rd HVAF spray systems in detail [12]. Between the splats, the oxide agglomerates show an insignificant chromium depletion but a qualitative oxide amount.

\subsection{Poteniodynamic Polarization Test Results in 3.5\% NaCl Solution}

The results of the corrosion tests of the AISI 316L HVAF coatings and the reference bulk materials are summarized in Figure 5, which illustrates representative curves for each case. During immersion of the samples in 3.5\% NaCl aqueous electrolyte for 15 min (Figure 5a), the OCP values of the AISI 316L coatings steadily decrease, which indicates a continuing corrosion. Thereby, the decline of the coatings deposited on mild steel is larger, resulting in a mean OCP value of $-136 \mathrm{mV} \pm 24 \mathrm{mV}$ compared to $+19 \mathrm{mV} \pm 1.7 \mathrm{mV}$ for AISI 316L- 
coated stainless steel. This difference can be explained by the electrolyte infiltration up to the substrate, which favors the formation of a galvanic pair between substrate and coating, and therefore the OCP represents a mixed potential. However, the OCP of the coated mild steel does not lie within the range of the mild steel bulk material reaching, $210 \mathrm{mV} \pm 24 \mathrm{mV}$ after $10 \mathrm{~min}$. An extension of the OCP measurement up to $3 \mathrm{~h}$ confirmed that a steady state for the AISI 316L coatings could not be confirmed but converged to the OCP of the mild steel substrate. Suegama et al. carried out immersion tests in aerated and aqueous $3.4 \%$ $\mathrm{NaCl}$ solution of HVOF AISI 316L-sprayed coatings with a thickness of $220 \mu \mathrm{m}$ and showed that the open circuit potential (OCP) stabilizes after $10 \mathrm{~h}$. The abrupt OCP descent within the first hour is attributed to chloride adsorption, dissolution of iron oxides by chloride ions, a change in oxygen and metallic ions concentration, which can affect a diffusion layer, alteration of the surface activity due to electrolyte infiltration into the coating, and metallic oxides formation and dissolution [15]. The OCP deviation of the stainless-steel coating and bulk reference can be referred to the coating's imperfections, which leads to crevice and galvanic corrosion within the coating. In addition, the OCP for the stainless-steel bulk material with $+101 \mathrm{mV} \pm 11 \mathrm{mV}$ and the coatings also differ significantly.

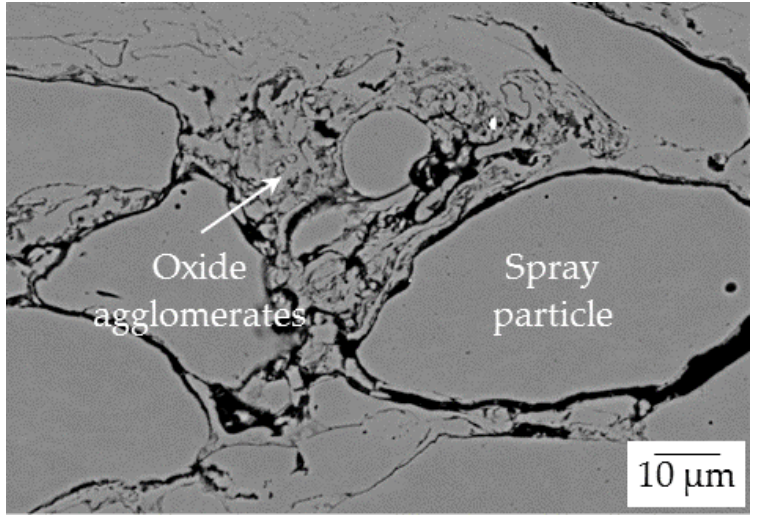

(a)

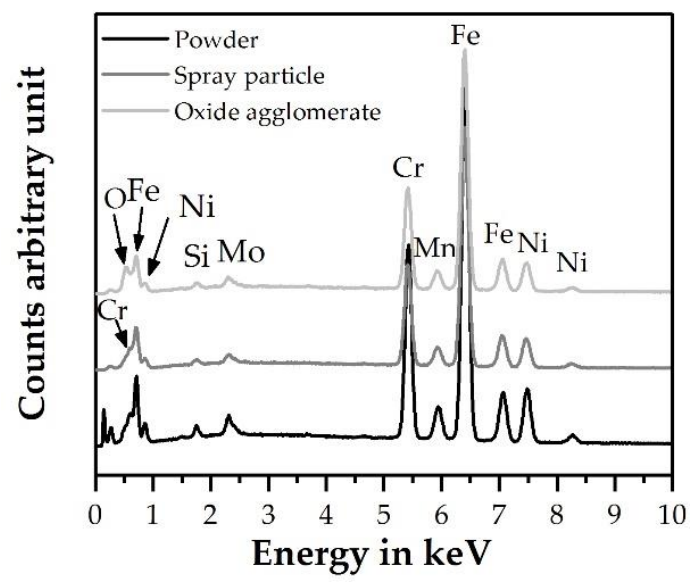

(b)

Figure 4. SEM investigation of an AISI 316L HVAF coating on mild steel in cross-section: (a) detailed BSD-SEM image and (b) EDX analysis of the powder and the coating.

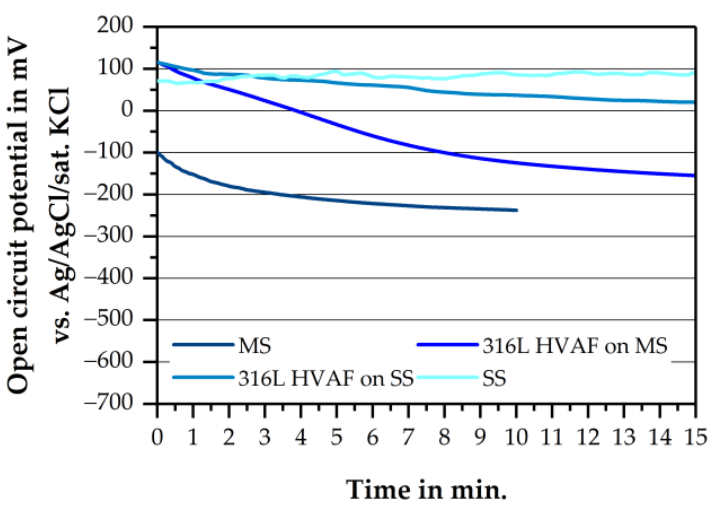

(a)

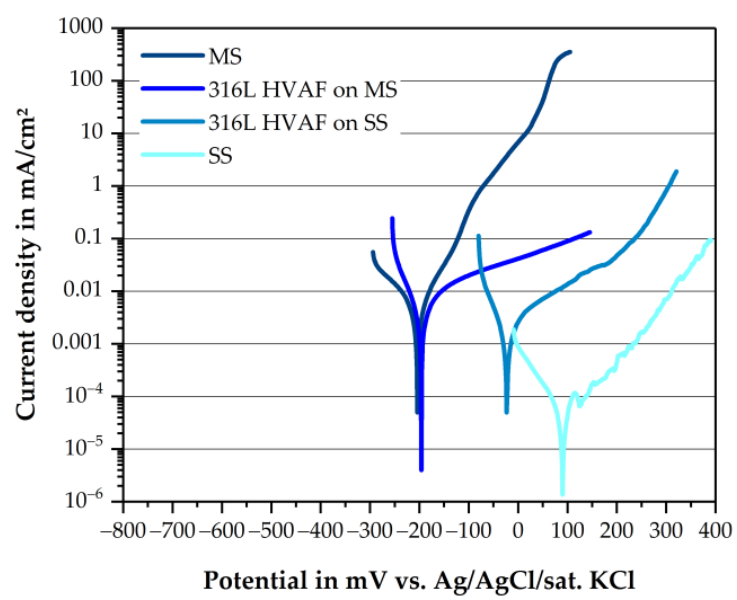

(b)

Figure 5. Representative curves of the electrochemical measurements in the $3.5 \% \mathrm{NaCl}$ solution for the AISI 316L HVAF coatings on mild steel (MS) and stainless steel (SS) and reference bulk materials, mild steel (MS) and stainless steel (SS): (a) OCP and (b) polarization curves. 
Figure $5 \mathrm{~b}$ shows the poteniodynamic polarization curves. The corrosion potential $\mathrm{E}_{\mathrm{Corr}}$ and the corrosion current densities $\mathrm{i}_{\mathrm{Corr}}$ of the AISI 316L-coated mild steel and the reference bulk material are on a similar level. The $\mathrm{E}_{\mathrm{Corr}}$ with $-179 \mathrm{mV} \pm 20 \mathrm{mV}$ of the AISI 316L coating on mild steel is lower compared to the OCP after $15 \mathrm{~min}$ of $-136 \mathrm{mV} \pm 24 \mathrm{mV}$, which might result from the coatings' active corrosion behavior. This behavior is further confirmed by the coated stainless-steel sample $\left(\mathrm{E}_{\mathrm{Corr}}=-23 \mathrm{mV} \pm 0.6 \mathrm{mV}, \mathrm{OCP}=+19 \mathrm{mV} \pm 1.7 \mathrm{mV}\right)$. Using a stainless-steel substrate also results in a shift of the $\mathrm{E}_{\mathrm{Corr}}$ to positive values and lower current densities, i.e., the ignoble substrate dominates the resulting corrosion parameters in the electrochemical-instrumented measurements. With regard to the anodic curve characteristics, the bulk mild steel shows the steepest ascent after passing $\mathrm{E}_{\mathrm{Corr}}$ of, $+17 \mathrm{mV} \pm 19 \mathrm{mV}$, which indicates an active corrosion. In comparison, the anodic slopes of the AISI 316L coatings rise gently, independently of the deposited substrate material. Nevertheless, the bulk stainless steel performs significantly better than the coatings $\left(\mathrm{E}_{\text {Corr }}=+88 \mathrm{mV} \pm 2 \mathrm{mV}\right)$. These results are as well reported and discussed in detail for AISI 316L HVOF and HVAF coatings in $[15,17,30,31]$.

For the evaluation of the corrosion attack, samples were examined after potentiodynamic polarization tests up to $+1000 \mathrm{mV}$ relative to the OCP using a stereomicroscope for top view and a light microscope for cross-sectional investigations (Figure 6). The top view images show a two-dimensional corrosion attack and material removal of the bulk mild steel and the AISI 316L coatings, with typical pitting occurring in bulk stainless steel (Figure 6, left column). Figure 6d,f demonstrates that the penetration of the aggressive chloride anions took place at the surface of the coating leaving a coating thickness of $>100 \mu \mathrm{m}$ and $>150 \mu \mathrm{m}$, respectively. García-Rodríguez et al. showed a similar attack at the external zone of AISI 316L HVOF coatings on magnesium substrates in 3.5\% $\mathrm{NaCl}$ electrolyte, when the coating was applied with optimized spray parameters achieving compact and dense coatings [20]. In the study, a scan rate of $1 \mathrm{mV} / \mathrm{s}$ was selected as well. It is to be noted that the scan rate has to be considered while evaluating the corrosion attack of thermal spray coatings. As indicated in Figure $6 \mathrm{~d}, \mathrm{f}$, the corrosion starts at inhomogeneities like oxide inclusions and microcracks, which favor crevice corrosion, as well as pitting occurs at single spray particles. The selective corrosion at the particle boundaries and the sites of oxide agglomerates, which correspond generally to $\mathrm{Cr}$ depleted areas as proved in Figure $4 \mathrm{~b}$, leads to fallen out particles at the surface. After etching of polished surfaces of 316L coatings deposited by HVAF and HVOF the same mechanisms are observed [24]. With progressive anodic polarization, reaching high current densities of $\sim 180 \mathrm{~mA} / \mathrm{cm}^{2}$, the coating is increasingly dissolved. For comparison with the gel electrolyte, Figure $6 \mathrm{~h}$ shows typical pitting corrosion in cross-section as observed for the reference stainless-steel material.

The results of the electrochemical corrosion test in aqueous $\mathrm{NaCl}$ electrolyte demonstrate for the AISI 316L HVAF coatings deposited on mild steel and stainless steel, respectively, that the different behavior in the potentiodynamic polarization curves (Figure $5 b$ ) nevertheless led to an equal corrosion attack of the coatings (Figure $6 \mathrm{c}-\mathrm{f}$ ). It is therefore not possible to evaluate the corrosion resistance of the coating system independent of the substrate material used.

\subsection{Potentiodynamic Polarization Test Results in 3.5\% NaCl Gel Electrolyte}

Figure 7a presents representative OCP measurements of the AISI 316L coatings and the reference materials in the $3.5 \% \mathrm{NaCl}$ gel electrolyte. Due to the substitution of the $\mathrm{Ag} / \mathrm{AgCl}$ reference electrode by a platinum wire, the OCPs are in other potential ranges and are slightly further spread in comparison to the aqueous electrolyte (Figure 5a). Likewise, however, the bulk stainless steel shows the highest value of $-54 \mathrm{mV} \pm 51 \mathrm{mV}$ and the bulk mild steel shows the lowest OCP value of $-595 \mathrm{mV} \pm 30 \mathrm{mV}$. However, the OCP curves of the AISI 316L HVAF coatings are almost independent of the substrate material used reaching $-274 \mathrm{mV} \pm 18 \mathrm{mV}$ for the mild steel and $-302 \mathrm{mV} \pm 16 \mathrm{mV}$ for the stainless-steel substrates after $15 \mathrm{~min}$. This already indicates that the use of the gel electrolyte can prevent 
infiltration of the coatings. All curves drop slightly at the beginning, but then remain largely constant.

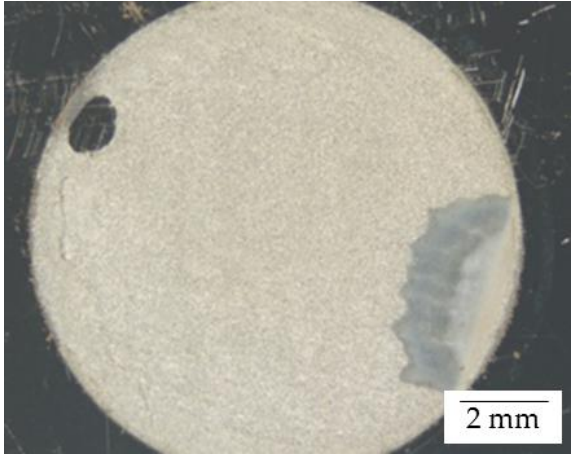

(a)

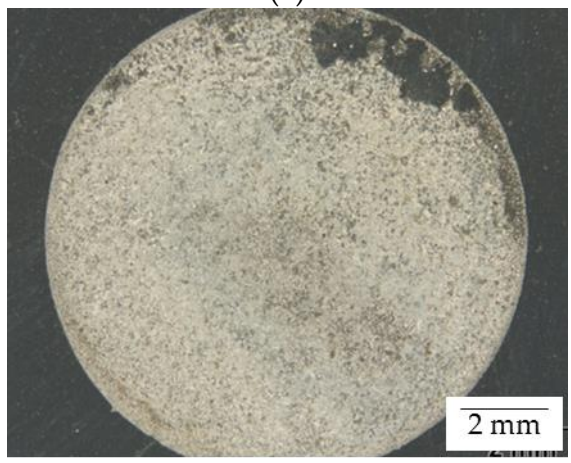

(c)

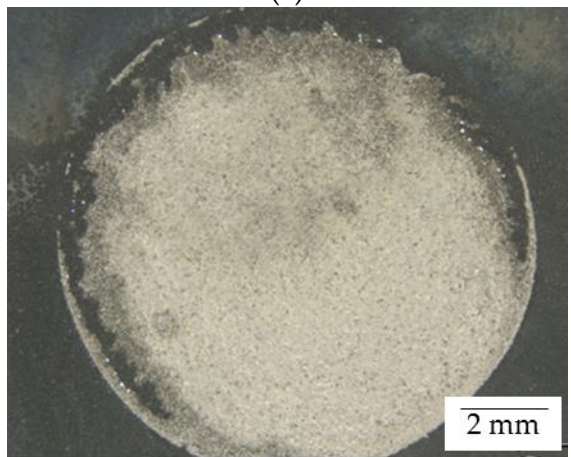

(e)

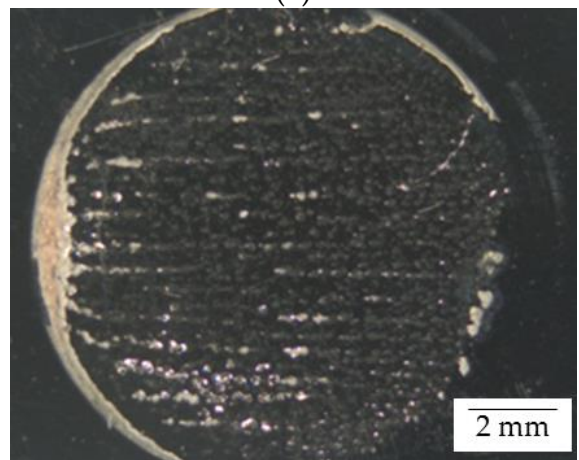

$(\mathrm{g})$

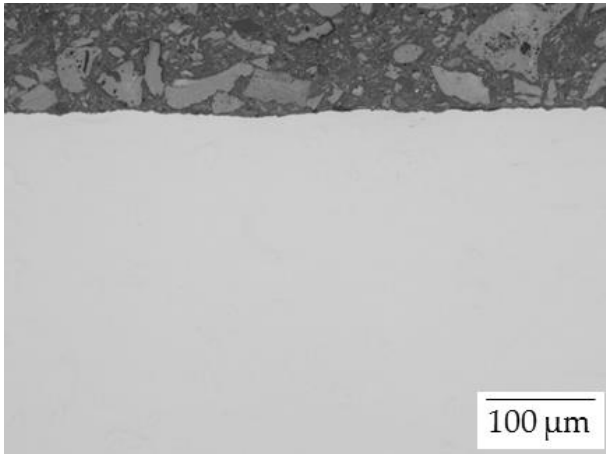

(b)

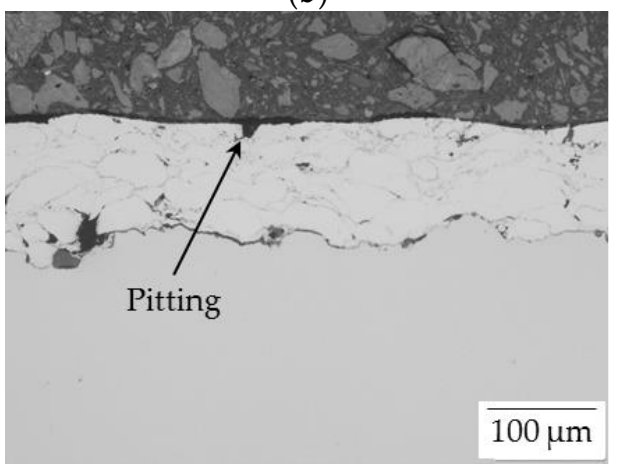

(d)

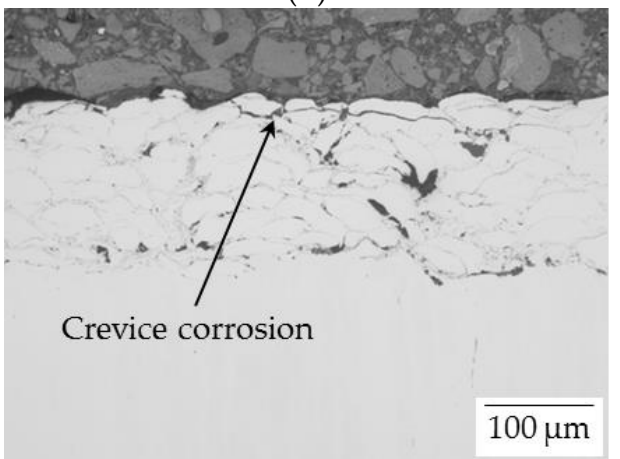

(f)

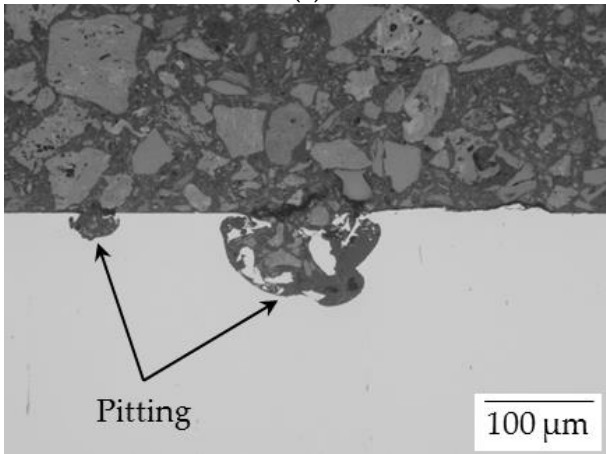

(h)

Figure 6. Representative top views and cross-sectional images of $(\mathbf{a}, \mathbf{b})$ reference material mild steel, (c,d) AISI 316L HVAF coating on mild steel, (e,f) AISI 316L HVAF coating on stainless steel, and $(\mathrm{g}, \mathrm{h})$ reference material stainless steel after potentiodynamic polarization in $3.5 \% \mathrm{NaCl}$ solution up to $+1000 \mathrm{mV}$ relative to the OCP. 


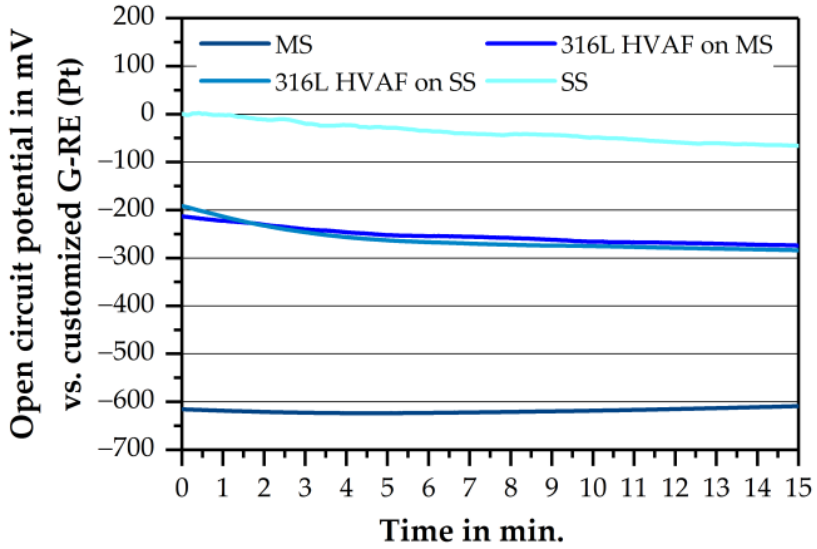

(a)

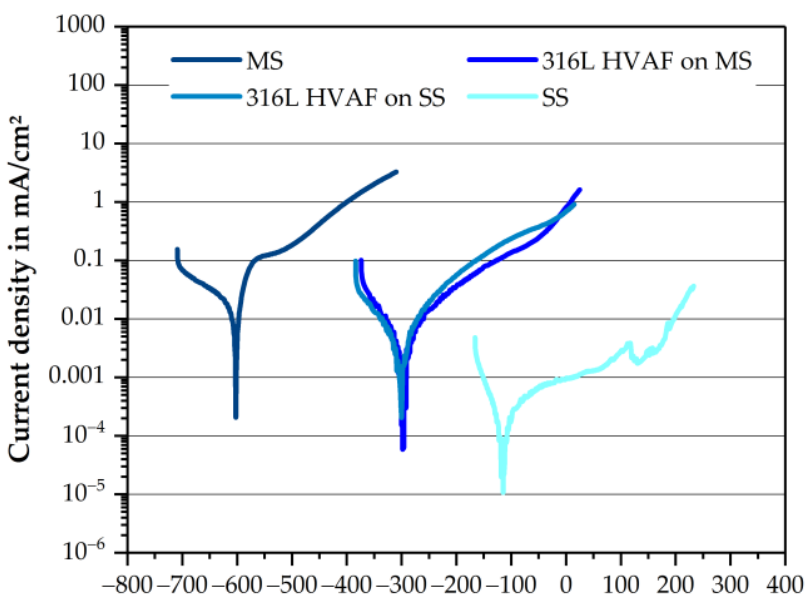

Potential in $\mathrm{mV}$ vs. customized G-RE (Pt)

(b)

Figure 7. Representative curves of the electrochemical measurements in the $3.5 \% \mathrm{NaCl}$ gel electrolyte for the AISI 316L HVAF coatings on mild steel (MS) and stainless steel (SS) and reference bulk materials, mild steel (MS) and stainless steel (SS): (a) OCP and (b) polarization curves.

Polarization curves are shown in Figure $7 \mathrm{~b}$. The $\mathrm{E}_{\mathrm{Corr}}$ are slightly shifted to lower values compared to the corresponding OCPs, which is valid for all considered samples. For the AISI 316L coatings, independent of the substrate material, the difference is about $20 \mathrm{mV}$, which is less than in the aqueous electrolyte. The absolute $\mathrm{E}_{\text {Corr }}$ values are $-296 \mathrm{mV} \pm 26 \mathrm{mV}$ for the coated mild steel and $-321 \mathrm{mV} \pm 20 \mathrm{mV}$ for stainless steel, respectively. The mild steel bulk material reaches $E_{\text {Corr }}$ values of $-589 \mathrm{mV} \pm 29 \mathrm{mV}$ and the stainless steel of $-90 \mathrm{mV} \pm 69 \mathrm{mV}$. As expected, the current densities determined for reference stainless steel are considerably lower than for mild steel. When looking at the anodic polarization curves, it is noticeable that compared to the aqueous electrolyte (Figure 5b), the curves rise steeply in the case of the AISI 316L coatings, whereas the curves for the bulk materials are flatter. This behavior can be justified by the fact that no electrolyte exchange takes place at the sample surface due to the immobility of the gel and thus, the corrosion progress is inhibited. In the case of AISI 316L HVAF coatings, the influence of the increasing corrosion area with longer measuring times is significantly reduced.

In order to compare the corrosion attack, some samples were anodically polarized up to $+1000 \mathrm{mV}$ relative to the $\mathrm{OCP}$ as carried out for the $3.5 \% \mathrm{NaCl}$ solution. By increasing the polarization range, all samples reached a maximum corrosion current value of $43 \mathrm{~mA} / \mathrm{cm}^{2}$, which is less than in the aqueous three-electrode arrangement $\left(\sim 180 \mathrm{~mA} / \mathrm{cm}^{2}\right)$. This must be considered when comparing the corrosion attack of both measuring cells. The top view images of the corroded samples show significant pitting for the AISI 316L coatings (Figure 8c,e) and the bulk stainless steel (Figure 8g), although the corrosion attack on the coatings is considerably more severe. One reason for this could be the high number of splat boundaries the sprayed coatings have, which are considered as potential starting points for corrosion. The cross-sections in Figure $8 \mathrm{~d}, \mathrm{f}$ confirm that crevice corrosion is inhibited due to the elimination of the coating infiltration, which leads to increased local pitting on the individual spray particles. No differences are recognizable between the AISI 316L coating on mild steel and stainless steel. Figure $8 \mathrm{~d}, \mathrm{f}, \mathrm{h}$ reveals hemispherical shaped pits in comparison to the provoked pits in the $\mathrm{NaCl}$ solution (Figure $6 \mathrm{~h}$ ). These findings are comparable with the study of Heyn, which compared the pitting corrosion appearance on stainless steel grade EN 1.4301 as bulk material after corrosion tests in Agar gel and liquid $\mathrm{NaCl}$ electrolytes [10]. The mild steel, on the other hand, failed to show pitting but a uniform corrosion attack (Figure $8 \mathrm{a}, \mathrm{b}$ ), which corresponds to results in $3.5 \% \mathrm{NaCl}$ solution (Figure 6a). 


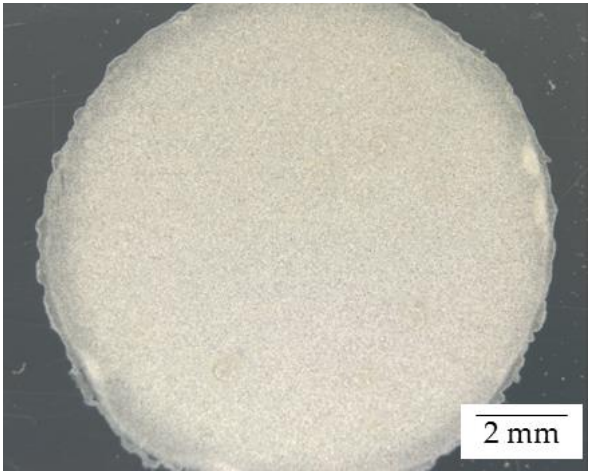

(a)

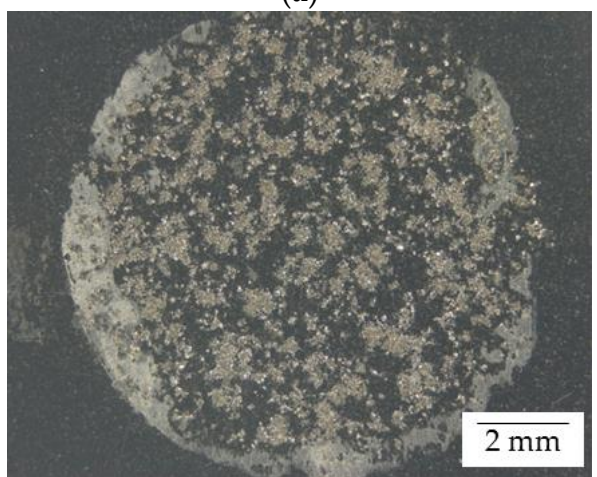

(c)

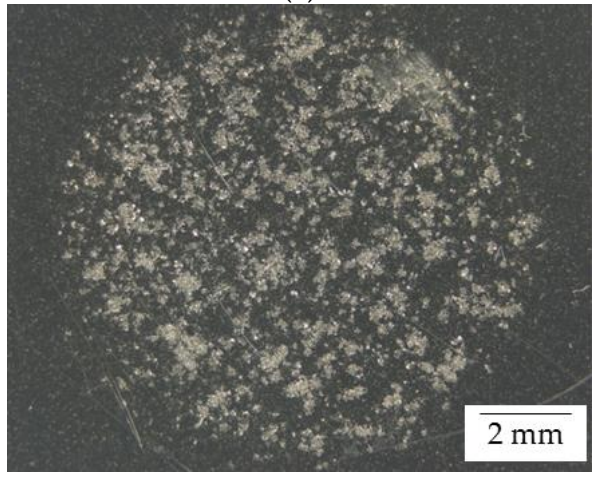

(e)

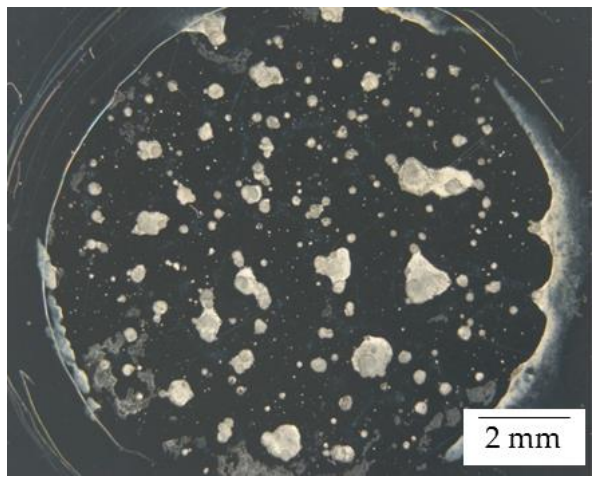

(g)

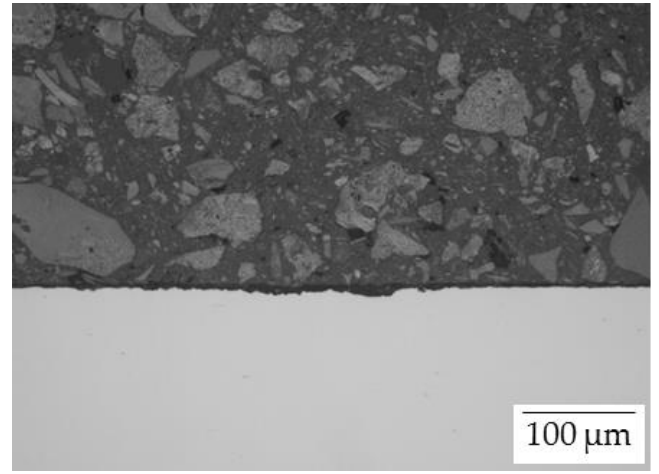

(b)

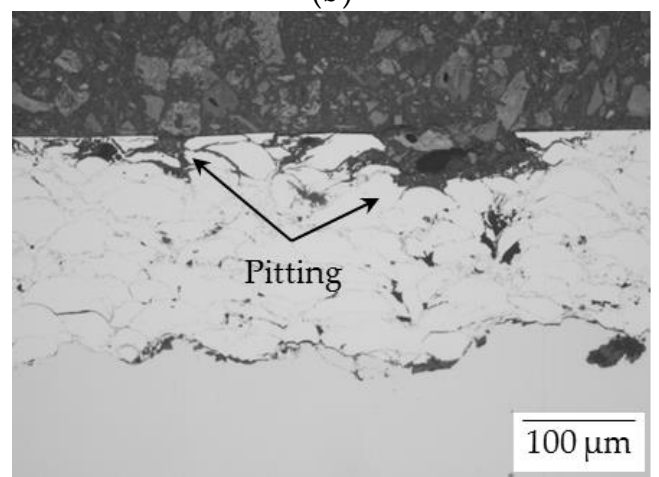

(d)

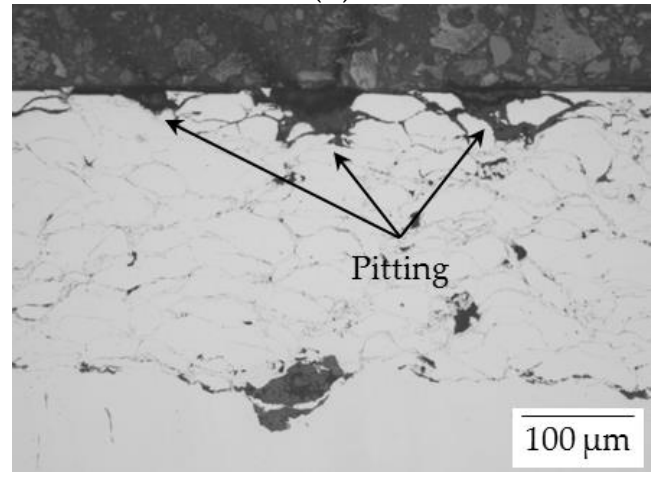

(f)

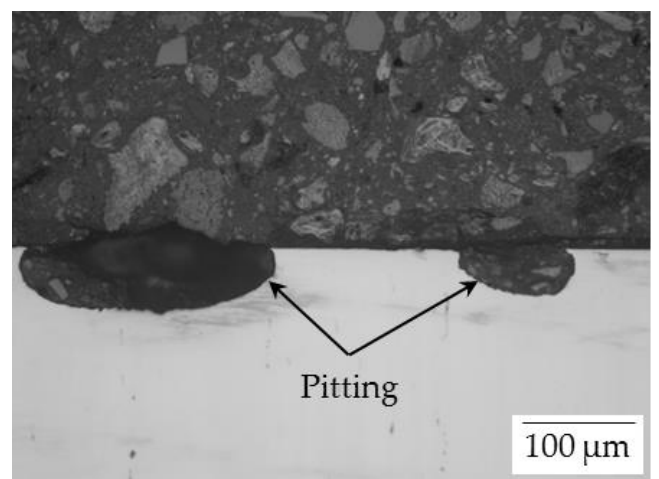

(h)

Figure 8. Representative top views and cross-sectional images of $(\mathbf{a}, \mathbf{b})$ reference material mild steel, (c,d) AISI 316L HVAF coating on mild steel, $(\mathbf{e}, \mathbf{f})$ AISI 316L HVAF coating on stainless steel, and $(\mathrm{g}, \mathbf{h})$ reference material stainless steel after potentiodynamic polarization in $3.5 \% \mathrm{NaCl}$ gel electrolyte up to $+1000 \mathrm{mV}$ relative to the OCP. 
The results of the electrochemical corrosion test in gelled $\mathrm{NaCl}$ electrolyte show that the high viscosity prevents the gel from infiltration of the coatings microstructure. Thus, the corrosion attack is limited to the upper micrometers at the surface and any corrosion at the coating-substrate interface can be eliminated. No difference can be observed in the potentiodynamic polarization curves (Figure 7) and the corrosion attack (Figure 8) of the AISI 316L HVAF coatings on mild steel or stainless steel. The results of the bulk materials prove that the targeted response of the aqueous electrolyte can be mimicked using gel electrolytes. In order to compare the corrosion attack of the coatings, potentiodynamic polarization tests with the same maximal corrosion densities as a termination criterion would be necessary to perform. Despite the different anodic slopes, the corrosion current density $\mathrm{i}_{\text {Corr }}$, which is determined in a narrow range around the $\mathrm{E}_{\mathrm{Corr}}$, can be used approximately for a comparative evaluation of the corrosion resistance of the AISI 316L HVAF-sprayed coatings in both media.

\subsection{Summary of the Corrosion Results in 3.5\% NaCl Aqueous and Gel Electrolyte}

As a summary, the $\mathrm{i}_{\text {Corr }}$ values, determined by means of Tafel analysis, of all tested samples are compared in Figure 9. In general, using the adapted measuring cell with the gel electrolyte the $\mathrm{i}_{\text {Corr }}$ values are higher than in the $3.5 \% \mathrm{NaCl}$ solution using the conventional three-electrode arrangement. Especially, mild steel shows significantly higher $\mathrm{i}_{\text {Corr }}$ values of $2.2 \times 10^{-2} \mathrm{~mA} / \mathrm{cm}^{2}$ $\pm 4.6 \times 10^{-4} \mathrm{~mA} / \mathrm{cm}^{2}$ in the gel compared to $4.4 \times 10^{-3} \mathrm{~mA} / \mathrm{cm}^{2} \pm 5.6 \times 10^{-4} \mathrm{~mA} / \mathrm{cm}^{2}$ in the aqueous electrolyte. The stainless steels obtain $\mathrm{i}_{\text {Corr }}$ of $5.6 \times 10^{-5} \mathrm{~mA} / \mathrm{cm}^{2} \pm 1.4 \times$ $10^{-5} \mathrm{~mA} / \mathrm{cm}^{2}$ and $2.6 \times 10^{-4} \mathrm{~mA} / \mathrm{cm}^{2} \pm 1.2 \times 10^{-4} \mathrm{~mA} / \mathrm{cm}^{2}$, respectively. This is probably caused by water evaporation during storage of the gel electrolyte, and thus, the chloride concentration was raised. An exception is the AISI 316L-coated mild steel, whose potentiodynamic polarization behavior is significantly influenced by the substrate material, when an aqueous electrolyte is used. The $i_{\text {Corr }}$ values with a mean of $4.2 \times 10^{-3} \mathrm{~mA} / \mathrm{cm}^{2} \pm 8.2 \times 10^{-4} \mathrm{~mA} / \mathrm{cm}^{2}$ are even comparable to the reference mild steel. The AISI 316L-coated stainless steel perform much better $\left(\mathrm{i}_{\text {Corr }}=1.5 \times 10^{-3} \mathrm{~mA} / \mathrm{cm}^{2} \pm 3.2 \times 10^{-4} \mathrm{~mA} / \mathrm{cm}^{2}\right)$. The AISI 316L HVAF coatings tested in the gel electrolyte confirm the same corrosion properties independent of the layer deposition on mild steel or stainless steel with $\mathrm{i}_{\text {Corr }}$ values of $3.5 \times 10^{-3} \mathrm{~mA} / \mathrm{cm}^{2}$ $\pm 4.9 \times 10^{-4} \mathrm{~mA} / \mathrm{cm}^{2}$ and $2.7 \times 10^{-3} \mathrm{~mA} / \mathrm{cm}^{2} \pm 6.1 \times 10^{-4} \mathrm{~mA} / \mathrm{cm}^{2}$, respectively, as discussed in $\mathrm{Ch}$. 3.3. The deviation among the individual measurements is within the usual accepted range for electrochemical-instrumented tests. Overall, the corrosion resistance decreases in the order bulk material stainless steel, AISI 316L HVAF coating, bulk material mild steel. 


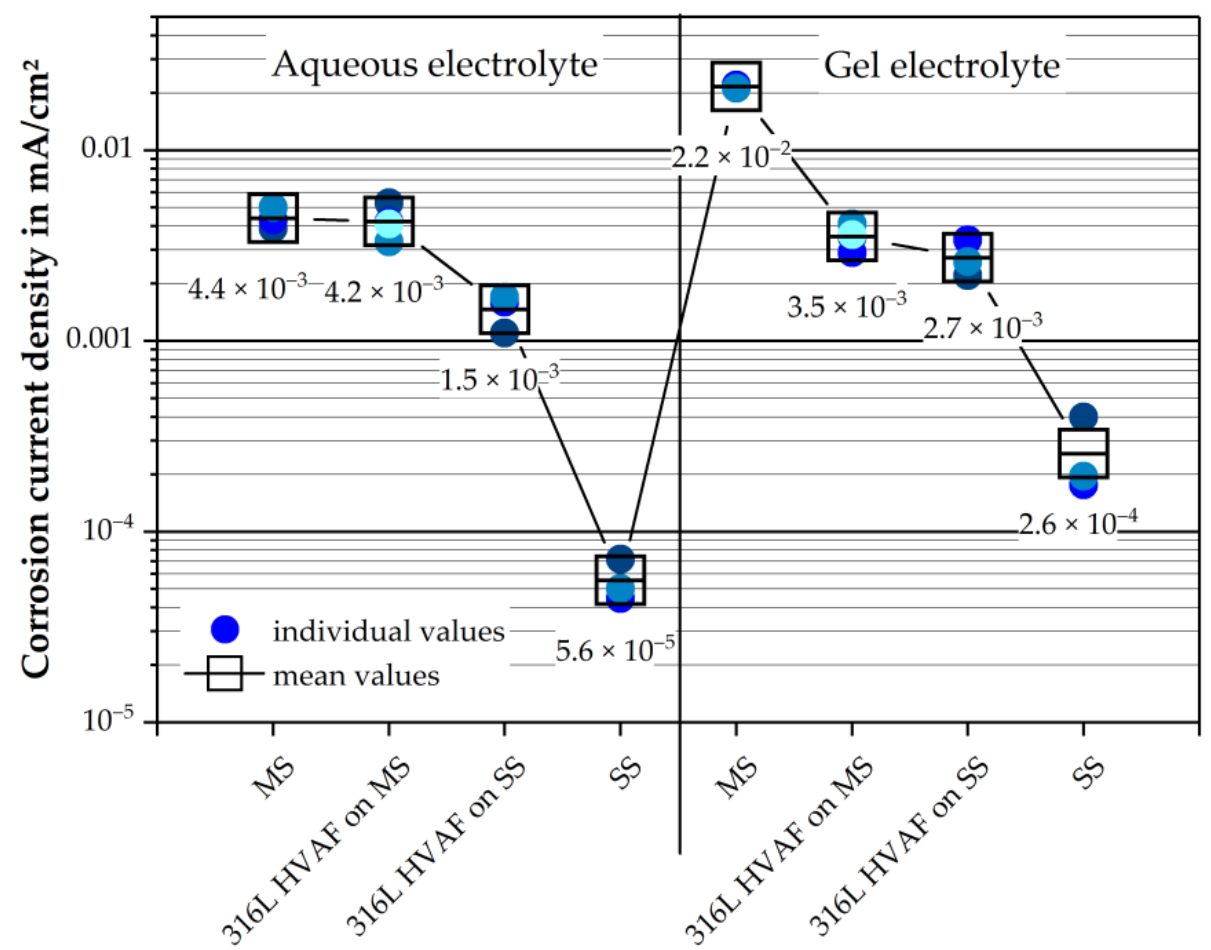

Figure 9. Corrosion current densities $\mathrm{i}_{\text {Corr }}$ of reference material mild steel (MS), AISI 316L HVAFsprayed coatings on mild steel (MS) and stainless steel (SS) and reference material stainless steel (SS) in $3.5 \% \mathrm{NaCl}$ aqueous and gel electrolyte determined by Tafel analysis.

\section{Conclusions}

In this study, a new approach to electrochemical-instrumented corrosion testing of thermal spray coatings using gel electrolytes was presented, which allows to study the corrosion behavior of the coating itself. Potentiodynamic polarization tests in $3.5 \% \mathrm{NaCl}$ solution in aqueous and gelled state were carried out comparing AISI 316L HVAF-coated samples on mild and stainless-steel substrates. Therefore, a measuring cell was adapted based on the three-electrode cell. The results of the polarization tests are as follows:

- The oxide agglomerates and oxidized splat boundaries are weak points and reduce the corrosion resistance of the HVAF-sprayed AISI 316L coatings.

- The infiltration of the coating microstructural characteristics is prevented by using gel electrolytes.

- $\quad$ Followed from this, the corrosion characteristic values such as OCP, $\mathrm{E}_{\mathrm{Corr}}$, and $\mathrm{i}_{\mathrm{Corr}}$ obtained are independent of whether the AISI 316L HVAF coating was deposited on mild steel or stainless-steel substrates when using gel electrolyte.

- In contrast, the aqueous electrolyte can penetrate the coating up to the substrate and hence, the characteristic values are significantly influenced.

- The $\mathrm{NaCl}$ gel electrolyte used allows the desired corrosive effect of the pitting attack to be mimicked.

Further experiments will focus on coatings produced with different spray parameters and spray processes in order to qualify the corrosion measurement with gel electrolytes for quality assurance during production. 
Author Contributions: Conceptualization, P.K., M.G., and T.L. (Thomas Lindner); funding acquisition, P.K., M.G., T.L. (Thomas Lindner), K.R.E., and C.P.; investigation, P.K., M.G., O.S., and C.P.; methodology, P.K., M.G., K.R.E., O.S., and C.P.; project administration, K.R.E., C.P., and T.L. (Thomas Lampke); supervision, T.L. (Thomas Lindner), K.R.E., C.P., and T.L. (Thomas Lampke); validation, P.K., M.G., O.S., and C.P.; writing—original draft, P.K., and M.G.; writing-review and editing, T.L. (Thomas Lindner), K.R.E., O.S., C.P., and T.L. (Thomas Lampke). All authors have read and agreed to the published version of the manuscript.

Funding: This research was funded by the Arbeitsgemeinschaft industrieller Forschungsvereinigung "Otto von Guericke" e.V. (AiF) in the framework of AiF-No. ZF413911SU9, ZF4752603SU9 and ZF4820401SU9. The APC was funded by the Deutsche Forschungsgemeinschaft (DFG, German Research Foundation) project number 491193532 and the Chemnitz University of Technology.

Institutional Review Board Statement: Not applicable.

Informed Consent Statement: Not applicable.

Data Availability Statement: Not applicable.

Acknowledgments: We would like to thank Zander, JELN Imprägnierung GmbH, for the production of the gel electrolytes.

Conflicts of Interest: Authors declare no conflict of interest. The funders had no role in the design of the study; in the collection, analyses, or interpretation of data; in the writing of the manuscript, or in the decision to publish the results.

\section{References}

1. Kauss, N.; Heyn, A.; Halle, T.; Rosemann, P. Detection of sensitization on aged lean duplex stainless steel with different electrochemical methods. Electrochim. Acta 2019, 317, 17-24. [CrossRef]

2. Burkert, A.; Klapper, H.S.; Lehmann, J. Novel strategies for assessing the pitting corrosion resistance of stainless steel surfaces. Mater. Corros. 2013, 64, 675-682. [CrossRef]

3. Rosemann, P.; Müller, T.; Babutzka, M.; Heyn, A. Influence of microstructure and surface treatment on the corrosion resistance of martensitic stainless steels 1.4116, 1.4034 and 1.4021. Mater. Corros. 2015, 66, 45-53. [CrossRef]

4. Ramírez-Barat, B.; Cano, E. Agar versus agarose gelled electrolyte for in situ corrosion studies on metallic cultural heritage. ChemElectroChem 2019, 6, 2553-2559. [CrossRef]

5. Monrrabal, G.; Ramírez-Barat, B.; Bautista, A.; Velasco, F.; Cano, E. Non-destructive electrochemical testing for stainless-steel components with complex geometry using innovative gel electrolytes. Metals 2018, 8, 500. [CrossRef]

6. Langklotz, U.; Babutzka, M.; Schneider, M.; Burkert, A. The combination of minimally invasive electrochemical investigation and FTIR-spectroscopy to analyse atmospheric corrosion product layers on zinc. Mater. Corros. 2019, 70, 1314-1325.

7. Monrrabal, G.; Guzmán, S.; Hamilton, I.E.; Bautista, A.; Velasco, F. Design of gel electrolytes for electrochemical studies on metal surfaces with complex geometry. Electrochim. Acta 2016, 220, 20-28. [CrossRef]

8. Ramírez-Barat, B.; Cano, E.; Letardi, P. Advances in the design of a gel-cell electrochemical sensor for corrosion measurements on metallic cultural heritage. Sens. Actuat. B Chem. 2018, 261, 572-580. [CrossRef]

9. Subbiah, K.; Velu, A.; Kwon, S.J.; Lee, H.S.; Rethinam, N.; Park, D.J. A novel in-situ corrosion monitoring electrode for reinforced concrete structures. Electrochim. Acta 2018, 259, 1129-1144. [CrossRef]

10. Heyn, A. Comparison of liquid and gel electrolytes for the investigation of pitting corrosion on stainless steel. IOP Conf. Ser. Mater. Sci. Eng. 2020, 882, 012010. [CrossRef]

11. Spark, A.J.; Cole, I.; Law, D.; Marney, D.; Ward, L. Investigation of agar as a soil analogue for corrosion testing. Mater. Corros. 2016, 67, 7-12. [CrossRef]

12. Valet, S.; Burkert, A.; Ebell, G.; Babutzka, M. Determination of the corrosion product layer resistance on zinc and electrolytically galvanized steel samples using gel electrolytes. Electrochim. Acta 2021, 385, 138191. [CrossRef]

13. Kutschmann, P.; Lindner, T.; Grimm, M.; Lampke, T. Electrochemical testing of thermal spray coatings using gel electrolytes. IOP Conf. Ser. Mater. Sci. Eng. 2021, 1147, 012031. [CrossRef]

14. Sadeghimeresht, E.; Markocsan, N. Electrochemical behavior of bilayer thermal-spray coatings in low-temperature corrosion protection. Coatings 2017, 7, 162. [CrossRef]

15. Suegama, P.H.; Fugivara, C.S.; Benedetti, A.V.; Fernández, J.; Delgado, J.; Guilemany, J.M. Electrochemical behavior of thermally sprayed stainless steel coatings in 3.4\% NaCl solution. Corros. Sci. 2005, 47, 605-620. [CrossRef]

16. Milanti, A.; Koivuluoto, H.; Vuoristo, P. Influence of the spray gun type on microstructure and properties of HVAF sprayed Fe-based corrosion resistant coatings. J. Spray Tech. 2015, 24, 1312-1322. [CrossRef]

17. Nascimento, A.R.C.; Gateman, S.M.; Mauzeroll, J.; Savoie, S.; Schulz, R.; Moreau, C. Electrochemical behavior, microstructure, and surface chemistry of thermal-sprayed stainless-steel coatings. Coatings 2019, 9, 835. [CrossRef] 
18. Dobler, K.; Kreye, H.; Schwetzke, R. Oxidation of stainless steel in the high velocity oxy-fuel process. J. Spray Tech. 2000, 9 , 407-413. [CrossRef]

19. Choi, S.J.; Lee, H.S.; Jang, J.W.; Yi, S. Corrosion behavior in a 3.5\% NaCl solution of amorphous coatings prepared through plasma-spray and cold-spray coating processes. Met. Mater. Int. 2014, 20, 1053-1057. [CrossRef]

20. García-Rodríguez, A.; López, A.L.; Torres, B.; Rams, B. 316L stainless steel coatings on ZE41 magnesium alloy using HVOF thermal spray for corrosion protection. Surf. Coat. Technol. 2016, 287, 9-19. [CrossRef]

21. Porcayo-Calderon, J.; Sotelo-Mazon, O.; Luna-Ramirez, A.; Porocayo-Palafox, E.; Salinas-Bravo, V.M.; Martinez-Gomez, L. Electrochemical behavior of $\mathrm{NiAl}$ and $\mathrm{Ni}_{3} \mathrm{Al}$ intermetallic coatings in $1.0 \mathrm{M} \mathrm{NaOH}$ Solution. Int. J. Electrochem. Sci. 2015, 10, 6241-6256.

22. Wu, J.; Zhang, S.D.; Sun, W.H.; Wang, J.Q. Influence of oxidation related structural defects in localized corrosion in HVAF-sprayed Fe-based metallic coatings. Surf. Coat. Technol. 2018, 335, 205-218. [CrossRef]

23. Sá Brito, V.R.S.; Bastos, I.N.; Costa, H.R.M. Corrosion resistance and characterization of metallic coatings deposited by thermal spray on carbon steel. Mater. Des. 2012, 41, 282-288. [CrossRef]

24. Zeng, Z.; Sakoda, N.; Tajiri, T.; Kuroda, S. Structure and corrosion behavior of 316L stainless steel coatings formed by HVAF spraying with and without sealing. Surf. Coat. Tech. 2008, 203, 284-290. [CrossRef]

25. Bolelli, G.; Lusvarghi, L.; Barletta, M. Heat treatment effects on the corrosion resistance of some HVOF-sprayed metal alloy coatings. Surf. Coat. Technol. 2008, 202, 4739-4847. [CrossRef]

26. Amudha, A.; Shashikala, H.D.; Nagaraja, H.S. Corrosion behavior and characterization of thermal sprayed coating of nickel chromium cermet on low carbon steel. Mater. Today 2018, 5, 16100-16105.

27. Orório, W.R.; Freitras, E.S.; Garcia, A. EIS and potentiodynamic polarization studies on immiscible monotectic Al-In alloys. Electrochim. Acta 2013, 102, 436-445.

28. Zhang, X.L.; Jiang, Z.H.; Yao, Z.P.; Song, Y.; Wu, Z.D. Effects of scan rate on the potentiodynamic polarization curve obtained to determine the Tafel slopes and corrosion density. Corros. Sci. 2009, 51, 581-587. [CrossRef]

29. McCafferty, E. Validation of corrosions rates measured by Tafel extrapolation method. Corros. Sci. 2005, 45, 3202-3215. [CrossRef]

30. Chidambaram, D.; Clayton, C.R.; Dorfman, M.R. Evaluation of the electrochemical behavior of HVOF-sprayed alloy coatings. Surf. Coat. Technol. 2004, 176, 307-317. [CrossRef]

31. Kuroda, S.; Fukushima, T.; Sasaki, M.; Kodama, T. Microstructure and corrosion resistance of HVOF sprayed 316L stainless steel and hastelloy C coatings. Mater. Trans. 2002, 43, 3177-3183. [CrossRef] 